


\section{Children Australia}

\section{is the quarterly journal of} The National Children's Bureau

of Australia, a division of

OZ CHILD - CHILDREN AUSTRALIA

19 Business Park Drive,

Notting Hill, Vic. 3168

PO Box 686, Mulgrave, Vic. 3170

Tel: (03) $5589100 \quad$ Fax (03) 5589243

The National Chlldren's Bureau of Australia is a division of $\mathrm{Oz}$ Child - Children Australia, an independent, non-government organisation committed to improving the quality of care and life opportunities avallable to children in Australla. NCBA plays an important advocacy role in support of children and through its publications, Information Services, conferences and research activities, promotes a national and multidisciplinary approach to children's issues.

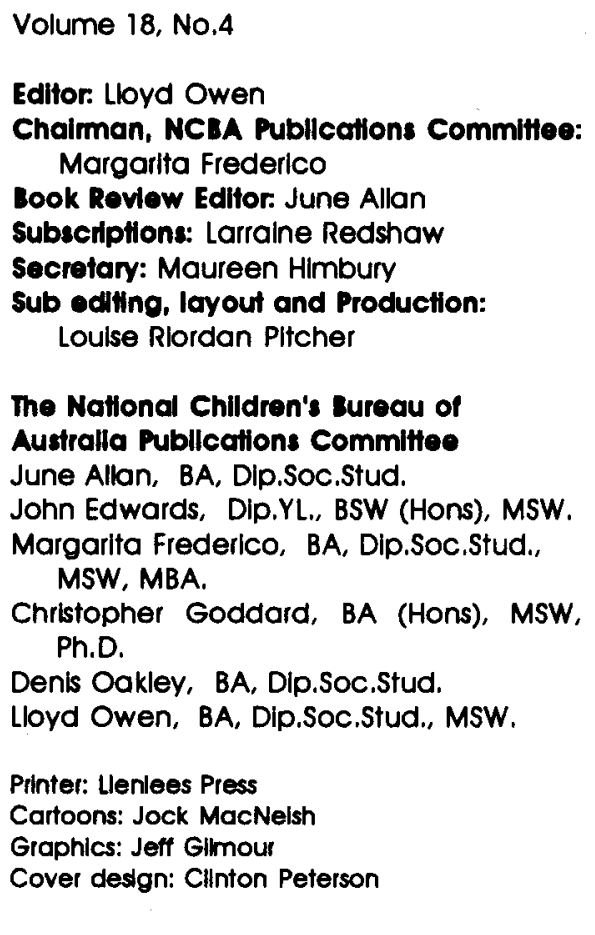

\section{NOTES TO CONTRIBUTORS}

1. Manuscripts should be typewritten on one side only on A4 paper, with double spacing and wide margins. Three hard copies should be submitted, and the approximate number of words stated. Wherever possible, material should also be submitted on IBM compatible diskette (5.25 or 3.5) in ASCII format.

2. References should be referred to in the text by giving, in brackets, the surname of the author and should be listed in alphabetical order at the end of the article as follows:

BOOKS: Author's name and initials; year of publication in brackets; title of book (in italics); publisher; page reference if appropriate.

ARTICLES: $\quad$ Author's name and initials; date of publication in brackets; title of article; abbreviated title of journal (in italics); volume and number.

3. Footnotes should be kept to a minimum.

4. Each article should be prefaced with a brief resume.

5. Contributors are invited to submit a brief biographical note and a current photograph suitable for printing.

6. All manuscripts submitted will be reviewed by three referees. Manuscripts may be accepted for publication, returned for revision or rejected. The Editor's decision is final.

7. All manuscripts and editorial communications should be addressed to:

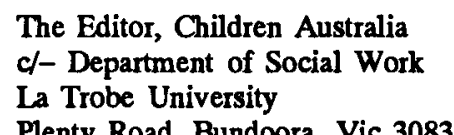

Plenty Road, Bundoora, Vic 3083

All book reviews should be addressed to: The Book Review Editor, at the above address.

8. All rights of reproduction are strictly reserved. 


\section{Children Australia}

\section{3 - The Year of the World's Indigenous Peoples}

- Inter-Agency Collaboration : Why is it so difficult? Can we do it better? . . . . . . . . . . 4 DOROTHY SCOTT

- News from our place... Latest news from AlCCAs \& MACs Australia-wide $\ldots \ldots \ldots \ldots \ldots$

- Bullying at School : It's hard not to feel helpless $\ldots \ldots \ldots \ldots \ldots \ldots \ldots \ldots \ldots \ldots$ PHILIP T. SLEE

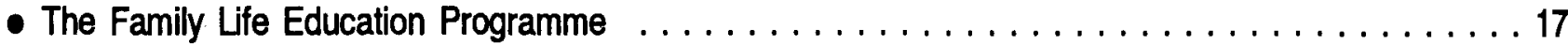
DAVID MELLOR AND SHANE STORER

- Recruiting Out-of-Home Caregivers for Children with an Intellectual Disability in the Shared Family Care Program $\ldots \ldots \ldots \ldots \ldots \ldots \ldots \ldots \ldots \ldots \ldots \ldots \ldots \ldots$ IIL VOLARD, CHRISTINE BAXTER AND CLIFF DA COSTA

- Schoolchildren's Perception of their Rights : a pilot study $\ldots \ldots \ldots \ldots \ldots \ldots \ldots \ldots$ J. NEVILLE TURNER

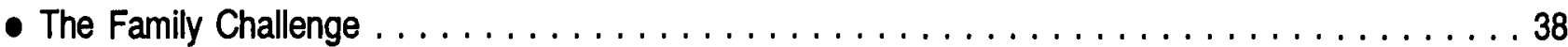
DON EDGAR

Not the last word: point and counterpoint

- Continuing to Abuse Children for a Living : Protecting children from abuse by professionals, Part $2 \ldots \ldots \ldots 39$ CHRIS GODDARD 